\title{
Fucoidan - A valuable source from the ocean to pharmaceutical
}

\author{
Pacheco D ${ }^{1}$, García-Poza $S^{1}$, Cotas J ${ }^{1}$, Gonçalves AMM ${ }^{1,2}$ and Pereira $L^{1 *}$ \\ ${ }^{1}$ MARE-Marine and Environmental Sciences Centre, Department of Life Sciences, Faculty of Sciences and Technology, University of Coimbra, 3001-456 Coimbra, \\ Portugal \\ ${ }^{2}$ Department of Biology and CESAM, University of Aveiro, 3810-193 Aveiro, Portugal
}

\begin{abstract}
Fucoidan is one of the most relevant polysaccharides synthesized by Phaeophyceae class (brown seaweeds). Previous research reveals widespread fucoidan bioactivity properties, like antitumoral, anti-inflammatory, antithrombotic or immunomodulatory.

Fucoidan extraction and purification methods are the current challenge, in order to obtain this biomolecule that presents different conformations within several seaweed species. The main goal of this mini review is to give an overview of fucoidan pharmaceutical applications research and to support the potential of this biomolecule to be explored by science and industry.
\end{abstract}

\section{Introduction}

Nowadays, the discovery of new biomolecules with bioactivities derived from natural sources is gaining more attention among the scientific community but it is important to promote eco-sustainability before the industry exploitation [1].

The relevance of marine resources, such as seaweeds, as a source of these bioactive compounds is attracting interest due to seaweeds' fast growth rate, the myriad of chemical substances produced and its widespread applications.

The high variability of compounds synthetized by seaweeds is an outcome of the adverse conditions to which they are exposed in their natural habitats [2].

Macroalgae are categorized into the phylum Chlorophyta, Rhodophyta and Ochrophyta (class Phaeophyceae), accordingly to its taxonomy. Brown seaweeds (Phaeophyceae) are a valuable source of polysaccharides, such as fucoidan, alginate, cellulose, laminarin and mannitol [3]. Thus, the composition and quantity of this biomolecules range according to the species and can fluctuate seasonally [4].

From the chemical point of view, fucoidans are complex polysaccharides $[5,6]$ and their bioactive properties are attracting interest due to their immunomodulation, anti-inflammatory, antitumor and antioxidant activities [7-9].

The main goal of this short review is to provide a general overview of fucoidan characterization and its pharmaceutical applications, including the most recent discoveries.

\section{Fucoidan characterization}

Seaweeds synthesize several polysaccharides with different conformations as main components of their cell wall $[4,10]$. Those which belong to class Phaeophyceae, particularly, synthesize fucoidan.
Fucoidan is a sulfated polysaccharide class that has the particularity of presenting a skeleton rich in fucose and composed by other sugars that differ between species (e.g.: mannose, galactose, glucose, xylose) (Figure 1) [11,12]. The first studies related to fucoidan chemical structure demonstrated that it was mainly a bone of $(1 \rightarrow 2)$ linked 4-O-sulphated fucopyranose residues. Yet, 3- linked fucose with 4 -sulphated groups were afterwards described to be

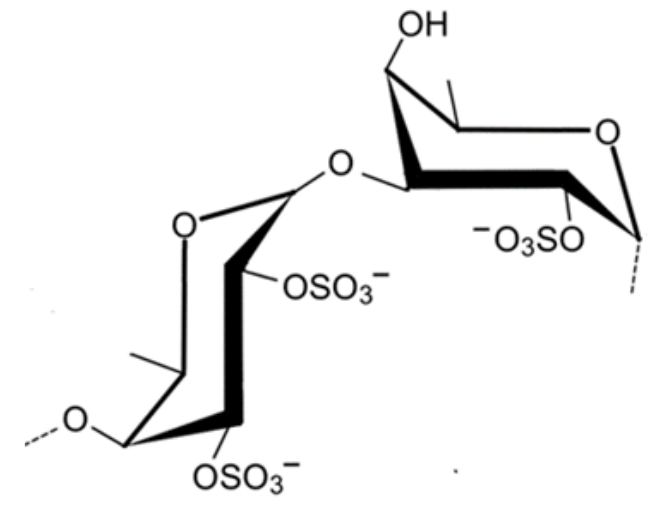

Figure 1. Idealized structure of the chemical units of Fucoidan

${ }^{\star}$ Correspondence to: Leonel Pereira, MARE-Marine and Environmental Sciences Centre, Department of Life Sciences, Faculty of Sciences and Technology, University of Coimbra, 3001-456 Coimbra, Portugal, Tel: +351-239-855-229, E-mail: leonel.pereira@uc.pt

Key words: seaweed, biodiversity, biomolecule, bioactive compound, pharmaceutical applications

Received: January 08, 2020; Accepted: January 21, 2020; Published: January 24 2020 
present around the fucose residues. Furthermore, it was determined to contain branches every 2-3 fucose residues [13].

Nevertheless, fucoidan represents a heterogeneous group of carbohydrates, comprised by galactose, mannose, xylose, uronic acid, sulphated and acetyl groups [1].

Seaweed derived fucoidans' are heterogenic due to variations in the content of carbohydrate units (L-fucopyranose and non-fucose) and non-carbohydrate groups (mainly sulfate and acetyl). Thus, the accurate analysis of its backbone structures and the precise determination of the location of minor structural elements is a challenge. The position of sulfate groups is important to the biological activities of sulfated polysaccharides. The methods of determining the sulfate position include infrared spectroscopy, desulfation, stability of sulfate esters to alkali and methylation analysis [11]

Therefore, research of fucoidan backbones and branches is the main targets of structural analysis [6].

Fucoidan is a secondary metabolite, in which its structural differences allow the differentiation between seaweed species [14].

For instance, structural differences affect fucoidan bioactivity such as fucoidan acetylation degree $[14,15]$, uronic acid and glucuronic acid concentration [3].

Monosaccharide backbone composition and other structural characteristics of the principal polymer chain (such as branching) are also relevant [16]. Fucoidan could be extracted and purified by several methodologies which influence its bioactivity $[11,17]$. Furthermore, during fucoidan extraction process, can occur the co-extraction of other compounds such as laminarin, alginic acid, proteins, terpenoids and polyphenols [18-21]. For this reason, the correct selection of algal species is a decisive factor to obtain fucoidan with a high yield of purity $[22,23]$.

The physicochemical properties of fucoidan are ideal for an emulsifier agent because fucoidan tends to form viscous gel without gelling. Thus, fucoidan has been validated to have higher emulsification indexes than carboxymethyl cellulose materials, particularly hydrocarbons. In addition, the capacity of fucoidan to form and stabilize emulsions is specific for certain hydrophobic compounds [24].

Low-molecular weight polysaccharides as fucoidan have a higher solubility, which contributes to their penetration into the cell [25].

The dynamic viscoelasticity of the fucoidan goes down linearly with rise in temperature. Fucoidan may flow under shearing and angular forces in aqueous solution including at high concentration (1.5\%) indicating that fucoidan properties are available for adhesion and connection on the surface of the materials. High values of the dynamic viscoelasticity in a large range of $\mathrm{pH}$ show that fucoidan molecules are stable in salts, acid and alkaline conditions [26].

This denotes that polymer of fucoidan is appropriate for commercial use in stabilizing, thickening and water holding agents in the food market, cosmetic and several more industries, for example, to stabilize protein oil-in-water emulsions [24,26].

The anti-adhesion feature of fucoidans is being utilized for the upgrade of oral hygiene and dental caries prevention [27].

In Japan fucoidan is commercialized as a component of drinks and tablets utilized as a nutritional supplement being manufactured on an industrial scale [26].

\section{Pharmaceutical applications}

Historically, seaweeds have a traditional usage, especially in Asian countries, as herbal medicine for the treatment of tumors, neurodegenerative diseases, urinary problems or gastrointestinal issues $[2,28]$. Brown seaweeds containing fucoidan are extensively used as part of the regular diet in East Asia, particularly in Japan, China, and Korea [29]. Despite their use in traditional Chinese and Japanese folk medicines, only in the current years they were commercialized as nutritional supplements and pharmaceutical products. They also began to be more studied and their compounds isolated [30].

Recently, fucoidan has been applied industrially in different sectors, such as cosmetics, dietary supplements and animal feeding supplements [8]. Still, fucoidan effects on terrestrial and aquatic animals have not been widely researched. In most of these studies was applied fucoidan crude extract, that can include non-fucoidan components (such as polyphenols and laminaran) with bioactivities which may interfere with the evaluation of bioactivities properties [5,7,8,29,31]. Table 1 shows several studies that point different seaweeds as a source of crude bioactive fucoidan and indicates that the average yield of extraction is around $1-20 \%$ [7]. It may therefore be necessary to consider that fucoidan diverse extraction and purification methodologies will present differences in their efficiency and yield [32].

There are new fucoidan based pharmaceutical products being developed to cardiovascular disease treatment and evaluated for its human safety before clinical trial (phase I) [33].

Nowadays, fucoidan is applied in some topical treatments and in other available dietary supplements. Furthermore, to evaluate the relevant fucoidan consumption and to aid in production, new measuring techniques have been developed. Due to the need of alternative approaches to antibiotic utilization in the food chain, microbiome modulation and anti-pathogenic effect are hopeful applications for fucoidans [9].

In vitro and in vivo tests were performed and confirmed antitumoral properties in fucoidans and an anti-metastatic effect in the development of cancer [34-39]. Nevertheless, the comparison of the available data is complex, due to the heterogeneity of these intricate polysaccharides, the strong influence of collecting and processing conditions, and the lack of tests with standardized purified products [38]. However, immune modulation is one of the most promising areas for the anticancer efficacy of fucoidan [39-41].

Fucoidan biological activities are wide, ranging from anticoagulant and anti-inflammatory, to antiviral, hepatoprotective and neuroprotective $[8,42,43]$.

Recent studies confirm the potential of fucoidan in tissue and bone engineering. Even in low concentrations, it could induce osteoblasts differentiation from stem cells. For instance, regenerative property of fucoidan is associated with its content of L-fucose and with the sulfate ester group in its polysaccharide skeleton [44-46].

\section{Conclusion}

It is important to consider that fucoidan yield differs within the selected extraction and purification methodologies. It is also necessary to consider methods suitable for scale-up, considering the costs, safety and its sustainability.

In future prospection, industrial fucoidan application will pass by the research of extraction methods and purification techniques that 
Table 1. Bioactive fucoidan dry weight yield of extraction from brown seaweeds (Phaeophyceae)

\begin{tabular}{|c|c|c|c|c|c|}
\hline Species & $\begin{array}{l}\text { DW Yield } \\
\quad(\%)\end{array}$ & Bioactivity & Concentration & Model & Ref. \\
\hline Cladosiphon sp. & 20 & $\begin{array}{l}\text { Anti-inflammatory; } \\
\text { Anti-cancer }\end{array}$ & $\begin{array}{l}2 \% \text { of high-molecular-weight fucoidan; } 6 \mathrm{~g} \\
\text { per day up to } 13 \text { months }\end{array}$ & $\begin{array}{l}\text { Rat; } \\
\text { Human }\end{array}$ & {$[7,47,48]$} \\
\hline Macrocystis pyrifera & 7.59 & Immunomodulatory & $\begin{array}{l}50 \mathrm{ml} \text { of a drink that contained } 1.5 \mathrm{~g} \text { of } \\
\text { fucoidan twice daily for } 6 \text { months }\end{array}$ & Human & {$[32,39,49]$} \\
\hline Ecklonia radiata & $3-5.4$ & n.d & n.d & n.d & {$[32]$} \\
\hline Seirococcus axillaris & 1.24 & n.d & n.d & n.d & {$[32]$} \\
\hline Saccharina latissima & 5.3 & Antitumor & $1-1000 \mu \mathrm{g} / \mathrm{mL}$ & $\begin{array}{l}\text { Raji cells (Burkitt lymphoma; B- } \\
\text { lineage) }\end{array}$ & {$[19,22]$} \\
\hline Fucus vesiculosus & 2.6 & $\begin{array}{c}\text { Neuroprotection; } \\
\text { Anticoagulant; Antitumor }\end{array}$ & $\begin{array}{c}\text { Between } 12.5 \text { to } 100 \mu \mathrm{g} / \mathrm{mL} ; \mathrm{c}: 0-5 \mu \mathrm{g} / 300 \\
\mu 1 ; 100 \mu \mathrm{g} / \mathrm{mL}\end{array}$ & $\begin{array}{l}\text { PC-12 cells; Normal pooled human } \\
\text { plasma ;MDA-MB-231 cells }\end{array}$ & {$[6,9,22]$} \\
\hline Fucus serratus & 2.9 & Antitumor; Antithrombin & $100 \mu \mathrm{g} / \mathrm{mL} ; 100 \mu \mathrm{g} / \mathrm{mL}$ & $\begin{array}{l}\text { MDA-MB-231 cells; Human } \\
\text { platelets }\end{array}$ & {$[6,22]$} \\
\hline Fucus evanescens & 4.5 & Antioxidant; Antithrombin & $1 \mathrm{mg} / \mathrm{mL} ; 2 \mathrm{mg} / \mathrm{mL} ; 250 \mu \mathrm{g} / \mathrm{ml} ; 100 \mu \mathrm{g} / \mathrm{mL}$ & $\begin{array}{l}\text { ABTS, TAC DPPH assay; Human } \\
\text { platelets }\end{array}$ & {$[6,22,50]$} \\
\hline Fucus distichus & n.d & Antithrombin; Antitumor & $1-200 \mu \mathrm{g} / \mathrm{mL}$ & RAW 264.7 cells & [38] \\
\hline Fucus spiralis & n.d & $\begin{array}{l}\text { Antifungal } \\
\text { Antioxidant }\end{array}$ & $\begin{array}{l}10 \text { to } 250 \mathrm{mg} \\
0.75 \mathrm{mg} / \mathrm{mL}\end{array}$ & $\begin{array}{l}\text { C. lagenarium, Aspergillus flavus } \\
\text { (fungi); } \\
\text { DPPH, FRAP }\end{array}$ & {$[51,52]$} \\
\hline Laminaria digitata & 2.2 & Antithrombin; Antitumor & $100 \mu \mathrm{g} / \mathrm{mL} ; 100 \mu \mathrm{g} / \mathrm{mL}$ & $\begin{array}{l}\text { Human platelets ;MDA-MB-231 } \\
\text { cells }\end{array}$ & {$[6,22]$} \\
\hline Dictyosiphon foeniculaceus & 2.0 & Anticoagulant & $129.5 \mu \mathrm{g} / \mathrm{mL}$ & Normal pooled human plasma & [22] \\
\hline Dictyopteris delicatula & n.d & $\begin{array}{l}\text { Anticoagulant, Antioxidant, } \\
\text { Antitumor }\end{array}$ & $100 \mathrm{mg} / \mathrm{mL}$ & $\begin{array}{c}\text { Citrate-treated normal human } \\
\text { plasma; HRSA, Superoxide Radical } \\
\text { Scavenging, Ferric Chelating; HeLa } \\
\text { cells }\end{array}$ & {$[53]$} \\
\hline Undaria pinnatifida & n.d & Neuroprotection; & Between 12.5 to $100 \mu \mathrm{g} / \mathrm{mL}$ & PC-12 cells & [9] \\
\hline $\begin{array}{l}\text { (Saccharina) Laminaria } \\
\text { japonica }\end{array}$ & 16 & $\begin{array}{l}\text { Antitumor; Antioxidant; } \\
\text { Antithrombin }\end{array}$ & $\begin{array}{l}0 \text { to } 2.0 \mathrm{mg} / \mathrm{ml} ; 0.5 \text { to } 8 \mathrm{mg} / \mathrm{ml}, 0.25-5 \mathrm{mg} / \\
\mathrm{ml} ; 2500 \mathrm{mg}\end{array}$ & $\begin{array}{l}\text { HeLa cells; DPPH, HRSA; } \\
\text { Adult horses }\end{array}$ & {$[29,54]$} \\
\hline Durvillaea potatorum & 6.3 & n.d & n.d & n.d & {$[32]$} \\
\hline Sargassum sp. & 19 & Antioxidant & $5 \mathrm{mg} / \mathrm{mL}, 0.25$ to $5 \mathrm{mg} / \mathrm{mL}, 0.25$ to $5 \mathrm{mg} / \mathrm{mL}$ & TAC, FRAP, HRSA & {$[24]$} \\
\hline Ascophyllum nodosum & 20 & Antioxidant & $3 \mathrm{mg} / \mathrm{mL}$ & DPPH & {$[55]$} \\
\hline $\begin{array}{l}\text { Padina boryana (formerly } \\
\text { Padina commersonii) }\end{array}$ & $8-12$ & Anti-inflammatory & $1-200 \mu \mathrm{g} / \mathrm{mL}$ & RAW 264.7 cells & {$[38]$} \\
\hline
\end{tabular}

*n.d: nothing to declare

allow chemical structure stability. Fucoidan is a promising natural compound targeted by the biomedical and pharmaceutical industries because of its promising therapeutic properties. Its low toxicity and wide bioactive components have already been confirmed in several in vitro and in vivo studies."

\section{Funding}

This work is financed by national funds through FCT Foundation for Science and Technology, I.P., within the scope of the projects UIDB/04292/2020 - MARE - Marine and Environmental Sciences Centre and UID/AMB/50017/2019 - CESAM - Centre for Environmental and Marine Studies. Sara García-Poza thanks to the project MENU - Marine Macroalgae: Alternative recipes for a daily nutritional diet (FA_05_2017_011) which co-financed this research, funded by the Blue Fund under Public Notice No. 5 - Blue Biotechnology. João Cotas thanks MARE, UC and Universidade Nova de Lisboa, through its Chemistry Department of the Faculty of Sciences and Technology within the scope of the research project "Algae in Gastronomy - Development of innovative techniques for conservation and use - Alga4Food" (MAR-01.03.01-FEAMP -0016). Diana Pacheco thanks to PTDC / BIA-CBI / 31144/2017 - POCI-01 project -0145-FEDER-031144 - MARINE INVADERS, co-financed by the ERDF through POCI (Operational Program Competitiveness and Internationalization) and by the Foundation for Science and Technology (FCT, IP). Ana M. M. Gonçalves acknowledges University of Coimbra for the contract IT057-18-7253.

\section{References}

1. Beratto-Ramos A, Agurto-Muñoz C, Pablo Vargas-Montalba J, Castillo R, del P (2020) Fourier-transform infrared imaging and multivariate analysis for direct identification of principal polysaccharides in brown seaweeds. Carbohydr Polym 230.

2. Olasehinde TA, Olaniran AO, Okoh AI (2019) Macroalgae as a Valuable Source of Naturally Occurring Bioactive Compounds for the Treatment of Alzheimer's Disease. Mar Drugs 17: 609 .

3. Ale MT, Mikkelsen JD (2011) Important determinants for fucoidan bioactivity: A critical review of structure-function relations and extraction methods for fucosecontaining sulfated polysaccharides from brown seaweeds. Mar Drugs 9: 2106-2130.

4. Manns D, Deutschle AL (2014) Methodology for quantitative determination of the carbohydrate composition of brown seaweeds (Laminariaceae). RSC Adv 4: 2573625746 .

5. Cui H, Wang Z, Liu J, Wang Y, Wang Z, et al. (2020) Effects of a highly purified fucoidan from Undaria pinnatifida on growth performance and intestine health status of gibel carp Carassius auratus gibelio. Aquac Nutr 26: 47-59.

6. Cumashi A, Ushakova NA, Preobrazhenskaya (2007) A comparative study of the anti-inflammatory, anticoagulant, antiangiogenic, and antiadhesive activities of nine different fucoidans from brown seaweeds. Glycobiology 17: 541-552.

7. Fitton JH (2015) Therapies from fucoidan; multifunctional marine polymers. Mar Drugs 9: 1731-1760.

8. Fitton JH, Stringer DN, Karpiniec SS (2015) Therapies from Fucoidan: An Update Mar Drugs 13: 5920-5946. [Crossref]

9. Fitton HJ, Stringer DS, Park AY, Karpiniec SN (2019) Therapies from Fucoidan: New Developments. Mar Drugs 17. [Crossref]

10. Narayan B, Chandini SK, Maeda H (2008) Composition, functionality and potential applications of seaweed lipids. 
11. Li B, Lu F, Wei X, Zhao R (2008) Fucoidan: structure and bioactivity. Molecules 13: 1671-1695. [Crossref]

12. Fitton JH (2011) Therapies from Fucoidan; Multifunctional Marine Polymers. Mar Drugs 9: 1731-1760.

13. Pereira L, Gheda SF, Ribeiro-claro PJA (2013) Analysis by Vibrational Spectroscopy of Seaweed Polysaccharides with Potential Use in Food, Pharmaceutical, and Cosmetic Industries. International Journal of Carbohydrate Chemistry 2013: 1-8.

14. Vishchuk OS, Ermakova SP, Zvyagintseva TN (2013) The fucoidans from brown algae of Far-Eastern seas: Anti-tumor activity and structure-function relationship. Food Chem 141: 1211-1217.

15. Usoltseva RV, Shevchenko NM, Malyarenko OS (2019) Fucoidans from brown algae Laminaria longipes and Saccharina cichorioides: Structural characteristics, anticancer and radiosensitizing activity in vitro. Carbohydr Polym 9.

16. Luthuli S, Wu S (2019) Therapeutic effects of Fucoidan: A review on recent studies. Mar Drugs 17. [Crossref]

17. Ale MT, Meyer AS (2013) Fucoidans from brown seaweeds: An update on structures, extraction techniques and use of enzymes as tools for structural elucidation. RSC Adv 3: 8131-8141

18. Lahrsen E, Liewert I, Alban S (2018) Gradual degradation of fucoidan from Fucus vesiculosus and its effect on structure, antioxidant and antiproliferative activities. Carbohydr Polym 192L 208-216.

19. Schneider T, Ehrig K, Liewert I, Alban S (2015) Interference with the CXCL12 CXCR4 axis as potential antitumor strategy: superiority of a sulfated galactofucan from the brown alga Saccharina latissima and Fucoidan over heparins. Glycobiology 25: $812-824$.

20. Heffernan N, Smyth TJ, Soler-Villa A, Fitzgerald RJ, Brunton NP (2014) Phenolic content and antioxidant activity of fractions obtained from selected Irish macroalgae species (Laminaria digitata, Fucus serratus, Gracilaria gracilis and Codium fragile). J Appl Phycol 27: 519-530.

21. Skriptsova AV, Shevchenko NM, Tarbeeva DV, Zvyagintseva TN (2012) Comparative study of polysaccharides from reproductive and sterile tissues of five brown seaweeds. Mar Biotechnol 14: 304-311.

22. Bittkau KS, Neupane S, Alban S (2020) Initial evaluation of six different brown algae species as source for crude bioactive fucoidans. Algal Res 45 .

23. Bittkau KS, Dörschmann P (2019) Comparison of the effects of fucoidans on the cell viability of tumor and non-tumor cell lines. Mar Drugs 17. [Crossref]

24. Hifney AF, Fawzy MA (2016) Industrial optimization of fucoidan extraction from Sargassum sp. and its potential antioxidant and emulsifying activities. Food Hydrocoll 54: 77-88.

25. Zuo T, Li X, Chang Y, Duan G, Yu L, et al. (2015) Dietary fucoidan of Acaudina molpadioides and its enzymatically degraded fragments could prevent intestinal mucositis induced by chemotherapy in mice. Food Funct 6: 415-422.

26. Tako M (2020) Rheological characteristics of fucoidan isolated from 1. Beratto-Ramos, A.; Agurto-Muñoz, C.; Pablo Vargas-Montalba, J.; Castillo, R. del P. Fourier-transform infrared imaging and multivariate analysis for direct identification of principal polysaccharides in brown seaweeds. Carbohydr Polym 230.

27. Oka S, Okabe M, Tsubura S (2020) Properties of fucoidans beneficial to oral healthcare. Odontology 108: 34-42. [Crossref]

28. Hong DD, Hien HTM (2004) Nutritional analysis of Vietnamese seaweeds for food and medicine. BioFactors 22: 323-325.

29. Zhao D, Xu J, Xu X (2018) Bioactivity of fucoidan extracted from Laminaria japonica using a novel procedure with high yield. Food Chem 245: 911-918. [Crossref]

30. Pádua D, Rocha E, Gargiulo D, Ramos AA (2015) Bioactive compounds from brown seaweeds: Phloroglucinol, fucoxanthin and fucoidan as promising therapeutic agents against breast cancer. Phytochem Lett 5 .

31. Dörschmann P, Bittkau KS (2019) Effects of fucoidans from five different brown algae on oxidative stress and VEGF interference in ocular cells. Mar Drugs 17. [Crossref]

32. Lorbeer AJ, Charoensiddhi S, Lahnstein J, Lars C (2017) Sequential extraction and characterization of fucoidans and alginates from Ecklonia radiata, Macrocystis pyrifera, Durvillaea potatorum, and Seirococcus axillaris. J Appl Phycol 29: 15151526.

33. Chauvierre C, Aid-Launais R (2019) Pharmaceutical development and safety evaluation of a GMP-grade fucoidan for molecular diagnosis of cardiovascular diseases. Mar Drugs 17: 699.
34. Senthilkumar K, Manivasagan P, Venkatesan J (2013) Brown seaweed fucoidan: Biological activity and apoptosis, growth signaling mechanism in cancer. Int $J$ Biol Macromol 2.

35. Kwak JY (2014) Fucoidan as a marine anticancer agent in preclinical development. Mar Drugs 12: 851-870.

36. Wu L, Sun J, Su X, Yu Q (2016) A review about the development of fucoidan in antitumor activity: Progress and challenges. Carbohydr Polym 6.

37. Wang P, Liu Z, Liu X, Teng H (2014) Anti-metastasis effect of fucoidan from Undaria pinnatifida sporophylls in mouse hepatocarcinoma Hca-F cells. PLoS One 9: e106071. [Crossref]

38. Asanka Sanjeewa KK, Jayawardena TU, Kim HS, Kim SY (2019) Fucoidan isolated from Padina commersonii inhibit LPS-induced inflammation in macrophages blocking TLR/NF-?B signal pathway. Carbohydr Polym 6.

39. Nagamine T, Kadena K, Tomori M, Nakajima K, Iha M (2020) Activation of NK cells in male cancer survivors by fucoidan extracted from Cladosiphon okamuranus. Mol Clin Oncol 12: 81-88. [Crossref]

40. Atashrazm F, Lowenthal RM, Woods GM, Holloway AF (2016) Fucoidan suppresses the growth of human acute promyelocytic leukemia cells in vitro and in vivo. $J$ Cell Physiol 231: 688-697.

41. Zhang W, Oda T, Yu Q, Jin JO (2015) Fucoidan from Macrocystis pyrifera has powerful immune-modulatory effects compared to three other fucoidans. Mar Drugs 13: 1084-1104.

42. Jiao G, Yu G, Wang W, Zhao X, Zhang J, et al. (2012) Properties of polysaccharides in several seaweeds from Atlantic Canada and their potential anti-influenza viral activities. J Ocean Univ China 11: 205-212.

43. Wijesekara I, Pangestuti R, Kim SKK (2011) Biological activities and potential health benefits of sulfated polysaccharides derived from marine algae. Carbohydr Polym 84 14-21

44. Jeong HS, Venkatesan J, Kim SK (2013) Hydroxyapatite-fucoidan nanocomposites for bone tissue engineering. Int J Biol Macromol 57: 138-141.

45. Lowe B, Venkatesan J, Anil S, Shim MS, Kim SK (2016) Preparation and characterization of chitosan-natural nano hydroxyapatite-fucoidan nanocomposites for bone tissue engineering. Int J Biol Macromol 93: 1479-1487. [Crossref]

46. Lowe B, Hardy JG, Walsh LJ (2020) Optimizing Nanohydroxyapatite Nanocomposite for Bone Tissue Engineering. ACS Omega 5: 1-9. [Crossref]

47. Nakazato K, Takada H, Iha M, Nagamine T(2010)Attenuation of N-nitrosodiethylamineinduced liver fibrosis by high-molecular-weight fucoidan derived from Cladosiphon okamuranus. J Gastroenterol Hepatol 25: 1692-1701.

48. Araya N, Takahashi K, Sato T, Nakamura T, Sawa C, et al. (2011) Fucoidan therapy decreases the proviral load in patients with human T-lymphotropic virus type-1associated neurological disease. Antivir Ther 16: 89-98. [Crossref]

49. Citkowska A, Szekalska M, Winnicka K (2019) Possibilities of Fucoidan Utilization in the Development of Pharmaceutical Dosage Forms. Mar Drugs 17: 458

50. Imbs TI, Skriptsova AV, Zvyagintseva TN (2014) Antioxidant activity of fucosecontaining sulfated polysaccharides obtained from Fucus evanescens by different extraction methods. J Appl Phycol 27: 545-553.

51. Michalak I, Chojnacka K (2015) Algae as production systems of bioactive compounds Eng Life Sci 15: 160-176.

52. Tierney MS, Smyth TJ, Hayes M, Soler-Vila A, Croft AK, et al. (2013) Influence of pressurised liquid extraction and solid-liquid extraction methods on the phenolic content and antioxidant activities of Irish macroalgae. Int J Food Sci Technol 48: 860-869.

53. Magalhaes KD, Costa LS, Fidelis GP, Oliveira RM, Nobre LTDB, et al. (2011) Anticoagulant, antioxidant and antitumor activities of Heterofucans from the seaweed Dictyopteris delicatula. Int J Mol Sci 12: 3352-3365.

54. Morello S, Southwood LL (2012) Effect of Intraperitoneal PERIDANTM concentrate adhesion reduction device on clinical findings, infection, and tissue healing in an adult horse jejunojejunostomy model. Vet Surg 41: 568-581.

55. Yuan Y, Macquarrie D (2015) Microwave assisted extraction of sulfated polysaccharides (fucoidan) from Ascophyllum nodosum and its antioxidant activity. Carbohydr Polym 129: 101-107.

Copyright: (C2020 Pacheco D. This is an open-access article distributed under the terms of the Creative Commons Attribution License, which permits unrestricted use, distribution, and reproduction in any medium, provided the original author and source are credited. 